\title{
PENINGKATAN KUALITAS SAMBAL FERMENTASI MELALUI PENAMBAHAN GARAM DAN BAHAN PENSTABIL
}

\section{IMPROVING QUALITY OF FERMENTATION "SAMBAL" THROUGH ADDING SALT AND STABILIZER}

\begin{abstract}
Antoni Alpindo
Program Studi Teknologi Pertanian Fakultas Pertanian, Universitas Dehasen Bengkulu
\end{abstract}

\begin{abstract}
ABSTRAK
Sambal adalah cabai yang menyerupai bubur dan biasanya ditambah bahan-bahan lain seperti garam ,bawang merah dan bawang putih. Untuk mningkatkan mutu sambal dapat dilakukan dengan cara fermentasi cabai. Penelitian ini bertujuan untuk mengetahui pengaruh konsentrasi garam dan penambahan CMC terhadap mutu sambal fermentasi.

Metode dalam penelitian meliputi proses pembuatan sambal cabai terdiri atas 2 tahap, yaitu fermntasi cabai merah dan cabai hijau dengan perlakuan penambahan konsentrasi garam (2\% dan 2,5\%). Kemudian pengolahan sambal fermentasi dengan penambahan bahan penstabil CMC dengan variasi perlakuan CMC (0\%, 0,5\% dan 1\%). Analisis pada penelitian ini meliputi analisis Total Plate Count, viskositas dan sifat organoleptik sambal fermentasi.

Dari hasil analisis TPC sambal fermentasi berkisar antara $0 \times 10^{3}$ hingga $1 \times 10^{3}$ dan analisis total padatan sambal fermentasi berkisar antara 26,90\% hingga 40,12\%, menunjukkan perbedaan yang nyata. Hasil uji organoleptik terhadap rasa sambal fermentasi berkisar antara 2,95 (agak suka) hingga 3,55 (agak suka) menunjukkan perbedaan yang nyata, terhadap warna sambal berkisar antara 3,05 (agak suka) hingga 3,45 (agak suka) menunjukkan tidak beda nyata dan hasil uji organoleptik terhadap tekstur sambal fermentasi berkisar antara 2,65 (tidak suka) hingga 3,6 (agak suka) menunjukkan perbedaan yang nyata.
\end{abstract}

Kata kunci : Kualitas sambal, fermentasi, cabai, garam, bahan pesntabil

\begin{abstract}
Sambal is a chili that resembles porridge and usually plus other ingredients such as salt, onion and garlic. For quality mningkatkan sauce can be made by fermentation chili. The treatment of each sample is fermntasi red chili and green chili by treatment with the addition of salt concentration ( $2 \%$ and $2.5 \%$ ). Then processing of fermented sauce with the addition of stabilizer CMC with the treatment variations $C M C(0 \%, 0.5 \%$ and $1 \%)$. The analysis in this study includes analysis of Total Plate Count, viscosity and organoleptic properties of fermented condiment. The results of the analysis of TPC sauce fermentation and total solids analysis showed significant differences sauce. The results of organoleptic test on taste and texture of the sauce meunjukan real difference and color condiment showed no significant difference
\end{abstract}

Keywords: Chilli quality, fermentation, chili, salt, stabilizers 


\section{PENDAHULUAN}

Sambal telah lama dikenal sebagai penggugah dan penambah selera makan. Sejalan dengan kemajuan zaman, sambal sekarang tidak hanya dibuat dirumah tangga dengan alat yang sederhana berupa cobet atau mutu, tetapi juga tersedia dalam bentuk sambal yang sudah jadi keluaran pabrik. Meskipun ragamnya tidak sebanyak sambal-sambal yang ada di Negara kita. Prospek pasar sambal saat ini cukup baik karena berkembang dengan cepat, sehingga pengembangan produk sambal masih terbuka luas karena masih ada jenis sambal yang belum dikembangkan menjadi sambal jadi.

Prospek pasarnya sangat baik karena pasarya berkembang dengan cepat, kompetisinya belum jenuh dan masih terbuka luas untuk pengembangan produk karena masih ada puluhan jenis sarnbal yang belum dikembangkan menjadi sambal jadi (Boga, 2004). Sambal adalah saus dari bahan dasar cabe yang menyerupai bubur dan biasanya ditambah bahan-bahan lain seperti garam ,bawang merah dan bawang putih. Sambal memilki cita rasa bervariasi menurut tingkat kepedasannya.

Cabe mengandung berbagai macam senyawa yang berguna bagi kesehatan manusia. Sun, dkk ( 2007) melaporkan cabe mengandung antioksidan yang berfungsi untuk menjaga tubuh dari serangan radikal bebas. Kandungan terbesar antioksidan adalah pada cabe hijau. Selain itu cabe memiliki kandungan vitamin $\mathrm{C}$ yang cukup tinggi pada cabe dapat memnuhi kebutuhan harian setiap orang, namun harus di konsumsi secukupnya untuk menhindari nyeri lambung (Anonim, 2009). Pengolahan cabe menjadi sambal diharapkan dapat meningkatkan nilai ekonomis cabe yang lebih tinggi jika dibandingkan dengan harga cabe segar. Pengolahan sambal dengan fermentasi bahan baku cabe diharapakan dapat meningkatkan mutu sambal cabe terutama cita rasa atau flavor dan dapat mengawetkan bahan pangan.

Fermentasi memiliki berbagai manfaat, antara lain untuk mengawetkan produk pangan, memberi cita rasa atau flavor, tekstur tertentu pada produk pangan. Fermentasi bukan hanya berfungsi sebagai pengawet sumber pangan, tetapi juga berkhasiat bagi kesehatan. Salah satumya adalah fermentasi dengan menggunakan bakteri asam laktat. Bakteri asam laktat yang tumbuh pada bahan pangan akan menyebabkan nilai $\mathrm{pH}$ pangan turun bahkan sampai di bawah 5.0, suasana ini akan menghambat pertumbuhan mikroorganisme patogen dan pembusuk diantaranya adalah bakteri proteus dan bakteri fekal (Escherichia coli) yaitu sejenis bakteri yang dapat mengganggu kesehatan manusia. Kelebihan sifat-sifat 
baik (positif) dari bakteri asam laktat dapat dimanfaatkan didalam proses pengolahan dan pengawetan bahan pangan (hasil hewan, hasil laut, sayuran dan buah-buahan).

Proses fermentasi cabe diharapkan dapat meningkatkan nilai gizi. Banyak bakteri asam laktat yang digunakan di dalam proses fermentasi dapat memproduksi bakteriosin potensial yang dapat bertindak sebagai pengawet makanan alami, baik yang tumbuh spontan ataupun diinginkan (ditambahkan kedalam bahan pangan).

Selain itu untuk menghasilkan sambal yang sesuai dengan karakteristik mutu sambal maka diperlukan penambahan bahan penstabil yang sesuai. Menurut Mustamanah (2012), pengemulsi, pemantap dan pengental (emulsifier, stabilizer) adalah bahan tambahan makanan yang dapat membantu terbentuknya terbentuknya atau memantapkan sistem dispersi yang homogen pada makanan. Bahan tambahan makanan ini biasanya ditambahkan pada makanan yang mengandung air dan minyak, misalnya saus selada, margarine, saus, sambal, dan es krim. Ketidakstabilan tersebut dapat dihambat dengan menambahkan bahan penstabil seperti Carboxylmethylcellulose (CMC).

CMC mampu menjadi penstabil dalam campuran dan memiliki fungsi pengental sehingga akan mempengaruhi nilai viskositas dari sambal. Diperlukan susunan campuran optimal antara rasio penambahan air dan konsentrasi CMC agar didapatkan viskositas yang disukai oleh konsumen. Sehubungan dengan penjelasan diatas maka diperlukan penelitian perbaikan kualitas sambal cabe merah dan hijau melalui proses fermentasi dan penambahan CMC sebagai bahan penstabil, sehingga kualitas bahan pada penggolahan sambal dapat meningkat

\section{METODE PENELITIAN}

\section{Alat dan Bahan}

Alat-alat yang digunakan dalam pengolahan sambal fermentasi yaitu blender, baskom, pisau, toples kaca, gelas ukur, thermometer, timbangan analitik, timbangan, sendok, dan wadah.

Sedangkan Bahan yang digunakan dalam penelitian pengolahan sambal fermentasi yaitu cabe merah keriting, cabe hijau, bawang merah, bawang putih, garam dapur, air dan gula

\section{Prosedur Penelitian}

\section{Proses fermentasi cabai}

Cabe merah $250 \mathrm{~g}$ dan cabe hijau $200 \mathrm{~g}$ dibersihkan dan dicuci. Ditambahkan garam dengan perlakuan $2 \%$ dan $2,5 \%$ serta gula masing-masing $0,5 \%$ setiap perlakuan dilarutkan dalam air. Cabe dimasukkan ke dalam toples dan dicampur dengan larutan garam dan gula. Kemudian 
toples ditutup dengan rapat dan difermentasi dengan waktu fermentasi selama 24 jam pada suhu ruang.

\section{Proses pengolahan sambal}

Campuran Cabe merah keriting dan cabe hijau sebanyak $450 \mathrm{~g}$ yang telah difermentasi dengan penambahan perlakuan konsentrasi garam 2\% dan 2,5\%, masing-masing dicampur dengan bawang merah $20 \%$, bawang putih $10 \%$, garam 5\% dan gula 13\%. Blansing selama 1 menit dengan suhu $80{ }^{\circ} \mathrm{C}$ dan Kemudian dihaluskan hingga menjadi seperti bubur. Bubur cabe dimasak dengan penambaahan CMC (0\%, 0,5\% dan 1\%) dan diaduk selama 30 menit. Sambal diisi ke dalam toples dan toples disetrilkan selama 30 menit. Sambal cabe di analisis Total Plate Count (TPC), total padat dan uji organoleptik (rasa, warna, tekstur).

\section{Metode Penelitian}

Rancangan yang digunakan dalam penelitian ini yaitu Rancangan Acak Lengkap (RAL) dengan perlakuan konsetrasi garam saat fermentasi dan konsetrasi CMC pada saat pengolahan sambal.

Konsentrasi Garam

G1 = Konsentrasi Garam $2 \%$

$\mathrm{G} 2=$ Konsentrasi Garam 2,5\%
Konsentrasi CMC

$$
\begin{array}{ll}
\mathrm{P} 1 & =\text { Konsentrasi CMC } 0 \% \\
\mathrm{P} 2 & =\text { Konsentrasi CMC 0,5\% } \\
\mathrm{P} 3 & =\text { Konsentrasi CMC 1\% }
\end{array}
$$

\section{HASIL DAN PEMBAHASAN}

\section{Hasil Analisis TPC Sambal Cabe}

Jumlah mikroba dalam suatu bahan pangan merupakan salah satu parameter mikrobiologis dalam menentukan layak atau tidaknya bahan pangan tersebut dikonsumsi. Analisis terhadap jumlah mikroba ditujukan untuk mengetahui jumlah total mikroba dalam suatu produk dan mengetahui tingkat pertumbuhannya selama penyimpanan. Jumlah mikroba dalam bahan pangan mempengaruhi cepat lambatnya kerusakan suatu bahan pangan. Hasil analisis TPC sambal cabai dengan perlakuan konsentrasi garam $(2 \%$ dan $2,5 \%)$ dan konsetrasi CMC (0\%, 0,5\% dan 1\%) dapat dilihat pada Tabel 1. 
Tabel 1. Nilai Rerata Analisis TPC Sambal Cabe

\begin{tabular}{|c|c|c|c|}
\hline Perlakuan & \multicolumn{3}{|c|}{ TPC (Total Plate Count) (koloni/g) } \\
\hline \multirow{2}{*}{ Garam } & \multicolumn{3}{|c|}{ CMC } \\
\cline { 2 - 4 } & $\mathbf{0 \%}$ & $\mathbf{0 , 5 \%}$ & $\mathbf{1 \%}$ \\
\hline $\mathbf{2 \%}$ & $1, \times 10^{3 \mathrm{a}}$ & $1, \times 10^{3 \mathrm{a}}$ & $1, \times 10^{3 \mathrm{a}}$ \\
\hline $\mathbf{2 , 5 \%}$ & $0, \times 10^{3 \mathrm{a}}$ & $1, \times 10^{3 \mathrm{a}}$ & $0, \times 10^{3 \mathrm{a}}$ \\
\hline
\end{tabular}

Keterangan : Angka yang diikuti oleh kode huruf yang berbeda menunjukkan adanya perbedaan yang nyata pada taraf signifikansi $5 \%$.

Tabel 1. menjelaskan nilai rerata analisis terhadap TPC sambal cabai dengan perlakuan konsetrasi garam $(2 \%$ dan $2,5 \%)$ dan penambahan $\mathrm{CMC}(0 \%, 0,5 \%$ dan $1 \%$ ) menunjukkan tidak beda nyata pada taraf signifikan 5\%.

Hasil rerata analisis TPC sambal cabe dengan perlakaun konsetrasi garam dan CMC berkisar anatar $0, \mathrm{x} 10^{3}$ hingga $1, \mathrm{x}$ $10^{3}$, berdasarkan SNI (2012) angka lempengan total yaitu maksimal $1 \times 10^{4}$, rerata analisis TPC sambal cabe memenuhi standara SNI 2012, dari hasil analisisi TPC meghasilkan jumlah koloni 1 , x $10^{3}$ yang berarti dalam 1 gram sampel terdapat 1000 koloni sedangkan pada standar SNI 2012 jumlah koloni yaitu $1 \mathrm{x}$ $10^{4}$ berarti dalam 1 gram sampel terdapat 10.000 koloni. Berdasarkan hasil analisis jumlah koloni pada sambal cabai sudah memenuhi persyaratan mutu karena masih memenuhi persyaratan ambang batas jumlah koloni sehingga sambal cabe layak untuk dikonsumsi. Rempah-rempah alami yaitu bawang putih, bawang merah dan cabai merah ataupun cabai hijau yang memiliki kemampuan antibakteri dalam menghambat pertumbuhan jumlah bakteri. Hal ini didukung oleh penelitian Wiryawan, dkk (2005) bahwa bawang putih dapat menghambat pertumbuhan bakteri pathogen Salmonella typhimurium serta penelitian Lingga dan Rustama (2005) bahwa ekstrak bawang putih yang dilarutkan dalam air bersifat antibakteri terhadap bakteri gram positif maupun gram negatif. Menurut Penelitian Surono (2013), bahwa ekstrak etanol bawang merah memiliki daya antibakteri terutama pada bakteri Staphylococcus aureus. Sedangkan menurut penelitian Sylvia (1996) Ekstrak etanol dari ketiga cabe (cabe besar, cabe keriting, cabe rawit) yang diuji menunjukkan aktivitas penghambatan pertumbuhan terbesar terhadap Staphylococcus aureus, Bacillus subtilis, Sarcina lutea dan Escherichia coli, serta terhadap fungi Candida albicans, dengan potensi yang relatif tidak berbeda. Dengan metode bioautografi, terlihat bahwa kapsaisin merupakan 
senyawa utama yang bertanggung jawab terhadap aktivitas antimikroba.

Hasil analisis terhadap TPC pada sambal dengan peralakuan konsetrasi garam pada proses fermentasi sambal cabe sebanyak $2 \%$ dan 2,5\% serta konsetrasi CMC 0\%, 0,5\% dan $1 \%$ menunjukkan jumlah koloni yang sesuai dengan standar mutu yaitu maksimal $1 \times 10^{4}$.

\section{Hasil Analisis Total Padatan Sambal \\ Cabe}

Hasil analisis total padatan sambal cabe dengan perlakuan konsentrasi garam (2\% dan 2,5\%) dan konsetrasi CMC (0\%, 0,5\% dan 1\%) dapat diihatt pada Tabel 2.

Tabel 2. menjelaskan nilai rerata analisis terhadap total padatan sambal cabe dengan perlakuan konsetrasi garam $(2 \%$ dan $2,5 \%)$ dan penambahan CMC (0\%, $0,5 \%$ dan $1 \%$ menunjukkan perbedaan yang nyata pada taraf signifikan $5 \%$. Hasil rerata total padatan sambal cabe dengan perlakuan garam $2 \%$ dan CMC $0 \%, 0,5 \%$ dan $1 \%$ masing-masing sebesar
$40,12 \%, \quad 37,51 \%, \quad 34,60 \%$, sedangkan rerata total padatan dengan perlakuan konsetrasi garam 2,5\% dan CMC 0\%, $0,5 \%$ dan $1 \%$ masing-masing sebesar $33,90 \%, 26,90 \%, 35,29 \%$. Hasil analisis terhadap total padatan sambal cabe dengan perlakuan konsentrasi garam 2\% dengan CMC 0\% sudah memenuhi persyaratan mutu berdasarkan SNI 2012 dengan total padatan minimal $40 \%$.

Penambahan CMC pada pengolahan sambal cabe berpengaruh terhadap nilai total padatan yang dihasilkan. CMC memiliki kemampuan yang cukup kuat dalam mengikat air bebas dalam sambal dan membentuk kerangka gel yang kuat. Menurut Tamaroh (2004), CMC mempunyai kernampuan membentuk gel hal inilah yang menyebabkan total padatan semakin tinggi. Penyimpanan juga mempengaruhi perubahan nilai total padatan. Hal ini karena adanya penguapan air pada proses pemanasan produk dan adanya garam sehingga menurunkan aktivitas air.

Tabel 2. Nilai Rerata Analisis Total Padatan Sambal Cabe

\begin{tabular}{|c|c|c|c|}
\hline Perlakuan & \multicolumn{3}{|c|}{ Total Padatan (\%) } \\
\hline \multirow{2}{*}{ Garam } & \multicolumn{3}{|c|}{ CMC } \\
\cline { 2 - 4 } & $\mathbf{0 \%}$ & $\mathbf{0 , 5 \%}$ & $\mathbf{1 \%}$ \\
\hline $\mathbf{2 \%}$ & $40,12^{\mathrm{a}}$ & $37,51^{\mathrm{b}}$ & $34,60^{\mathrm{c}}$ \\
\hline $\mathbf{2 , 5 \%}$ & $33,90^{\mathrm{d}}$ & $26,90^{\mathrm{e}}$ & $35,29^{\mathrm{f}}$ \\
\hline
\end{tabular}

Keterangan : Angka yang diikuti oleh kode huruf yang berbeda menunjukkan adanya perbedaan yang nyata pada taraf signifikansi $5 \%$. 
Hal ini sesuai dengan pernyataan Purnomo (1995) bahwa pada prose fermentasi sayur, penambahan garam dapur dapat menurunkan nilai aktivitas air, keadaan ini ditunjang oleh suhu yang berperan dalam kegiatan mikroorganisme selama proses fermentasi.

\section{Uji Organoleptik Warna Sambal Cabe}

Warna merupakan salah satu unsur yang dapat dijadikan indikator mutu pangan. Makanan dengan nilai gizi tinggi bila tidak didukung dengan warna yang sesuai dapat menurunkan mutu produk tersebut (Anggraini, 2011). Hasil uji organoleptik warna sambal cabe dengan perlakuan konsentrasi garam (2\% dan 2,5\%) dan konsetrasi CMC (0\%, 0,5\% dan 1\%).

Tabel 3 menjelaskan nilai rerata uji organoleptik terhadap rasa sambal cabe dengan perlakuan konsentarsi garam $2 \%$ dan $2,5 \%$ serta penambahan CMC pada pengolahan sambal cabe dengan konsentrasi $0 \%, 1 \%$ dan 5\% menunjukkan tidak ada perbedaan yang nyata pada taraf signifikan 5\%. Nilai rerata uji organoleptik warna sambal cabe dengan perlakuan konsetrasi garam 2\% dan 2,5\% serta penambahan CMC 0\%, 0,5\% dan $1 \%$ masing-masing yaitu 3,05 (agak suka), 3,20 (agak suka), 3,35\% (agak suka), 3,10 (agak suka), 3,30 (agak suka), dan 3,45 (agak suka). Penambahan CMC tidak memberikan pengaruh terhadap warna smabal, CMC merupakan zat dengan warna putih atau sedikit kekuningan, tidak berbau dan tidak berasa, berbentuk granula yang halus atau bubuk yang bersifat higroskopis (Inchem, 2002).

Hasil uji organoleptik terhadap warna sambal cabe yang dihasilkan yaitu merah gelap disebabkan oleh kombinasi bahan baku yang digunakan berupa cabe merah dan cabe hijau dimana jumlah perbandingan bahan baku cabe merah dan hijau yaitu 250 gr : 200 gr.

\section{Tabel 3. Nilai Rerata Uji Organoleptik Warna Sambal Cabe}

\begin{tabular}{|c|c|c|c|}
\hline Perlakuan & \multicolumn{3}{|c|}{ Warna } \\
\hline \multirow{2}{*}{ Garam } & \multicolumn{3}{|c|}{ CMC } \\
\cline { 2 - 4 } & $\mathbf{0 \%}$ & $\mathbf{0 , 5 \%}$ & $\mathbf{1 \%}$ \\
\hline $\mathbf{2 \%}$ & $3,05^{\text {a }}$ & $3,20^{\text {a }}$ & $3,25^{\text {a }}$ \\
\hline $\mathbf{2 , 5 \%}$ & $3,10^{\text {a }}$ & $3,30^{\text {a }}$ & $3,45^{\text {a }}$ \\
\hline
\end{tabular}

Ket : Angka yang diikuti oleh kode huruf yang berbeda menunjukkan adanya perbedaan yang nyata pada taraf signifikansi 5\%. Ket Skala : 1= sangat tidak suka; 2 $=$ tidak suka; $3=$ agak suka; $4=$ suka; $5=$ sangat suka 
Warna merah menurut Purseglove (2003) disebabkan pula oleh pigmen karotenoid yang warnanya bervariasi dari kuning jingga sampai merah gelap, pendukung warna merah pada kultivar Capsicum annuиm adalah capsantin dan capsorubin, sedangkan warna hijau pada cabai hijau karena klorofil. Warna dari sambal cabe dapat disebabkan oleh proses pemasakan, zat warna dari cabe akan terdegradasi karena pemanasan.

\section{Uji Organoletik Rasa Sambal Cabe}

Cita rasa merupakan suatu kesan yang diterima melalui saraf indera pengecapan, yaitu lidah. Sebagai hasil hadirnya senyawa-senyawa yang larut dalam air (Anonim, 2007). Hasil uji organoleptik rasa sambal cabe dengan perlakuan konsentrasi garam (2\% dan 2,5\%) dan konsetrasi CMC (0\%, 0,5\% dan 1\%).

Tabel 4 menjelaskan nilai rerata uji organoleptik terhadap rasa sambal cabe dengan perlakuan konsentarsi garam $2 \%$ dan $2,5 \%$ serta penambahan CMC pada pengolahan sambal cabe dengan konsentrasi $0 \%, 1 \%$ dan 5\% menunjukkan perbedaan yang nyata pada taraf signifikan 5\%. Nilai rerata uji organoleptik terhadap rasa sambal cabe yang dihasilkan dengan perlakuan konsentrasi garam $2 \%$ dan CMC $0 \%$, $0,5 \%$ dan $1 \%$ masing-masing yaitu 3,25 (agak suka), 3,30 (agak suka) dan 3,55 (agak suka), sedangkan perlakuan dengan konsentrasi garam 2,5\% dan CMC dengan konsentrasi $0 \%, 0,5 \%$ dan $1 \%$ masingmasing yaitu 3,02 (agak suka), 2,95 (agak suka) dan 3,45 (agak suka).

Hasil uji organoleptik terhadap rasa sambal menunjukkan pada skala agak suka, rasa yang ditimbulkan dari sambal cabe yaitu rasa pedas, manis dan gurih dapat disebabkan dari penambahan rempah pada proses pengolahan smabal cabe.

\section{Tabel 4. Nilai Rerata Uji Organoleptik Rasa Sambal Cabe}

\begin{tabular}{|c|c|c|c|}
\hline Perlakuan & \multicolumn{3}{|c|}{ Rasa } \\
\hline \multirow{2}{*}{ Garam } & \multicolumn{3}{|c|}{ CMC } \\
\cline { 2 - 4 } & $\mathbf{0 \%}$ & $\mathbf{0 , 5 \%}$ & $\mathbf{1 \%}$ \\
\hline $\mathbf{2 \%}$ & $3,25^{\mathrm{ab}}$ & $3,30^{\mathrm{ab}}$ & $3,55^{\mathrm{a}}$ \\
\hline $\mathbf{2 , 5 \%}$ & $3,20^{\mathrm{ab}}$ & $2,95^{\mathrm{b}}$ & $3,45^{\mathrm{ab}}$ \\
\hline
\end{tabular}

Ket : Angka yang diikuti oleh kode huruf yang berbeda menunjukkan adanya perbedaan yang nyata pada taraf signifikansi $5 \%$. Ket Skala : $1=$ sangat tidak suka; 2 $=$ tidak suka; $3=$ agak suka; $4=$ suka; $5=$ sangat suka 
Menurut Furia (1968), cabe merah mengandung oleoresin yang menimbulkan rasa pedas, warna merah dan cita rasa yang khas. Menurut Rahayu (2000), kandungan minyak atsiri pada bawang putih dapat menimbulkan aroma dan memberikan cita rasa yang gurih Menurut Suprapti (2000), garam yang ditambahkan juga berpengaruh terhadap rasa karena garam merupakan pemberi dan penguat rasa bumbu yang sudah ada sebelumnya Penggunaan sukrosa yang sesuai juga memberikan kontribusi manis pada sambal cabe.

\section{Uji Organoleptik Tekstur Sambal Cabe}

Untuk dapat merasakan tekstur suatu produk digunakan indera peraba. Tekstur juga menjadi salah satu faktor penentu kualitas yang perlu diperhatikan. Hasil uji organoleptik tekstur sambal cabe dengan perlakuan konsentrasi garam $(2 \%$ dan $2,5 \%)$ dan konsetrasi CMC (0\%, $0,5 \%$ dan $1 \%)$.

Tabel 5 menjelaskan nilai rerata uji organoleptik terhadap rasa sambal cabe dengan perlakuan konsentrasi garam $2 \%$ dan $2,5 \%$ serta penambahan CMC pada pengolahan sambal cabe dengan konsentrasi $0 \%, 1 \%$ dan 5\% menunjukkan tidak ada perbedaan yang nyata pada taraf signifikan 5\%. Nilai uji organoleptik terhadap tekstur sambal cabe dengan perlakuan konsentrasi garam $2 \%$ dan $2,5 \%$ serta CMC $0 \%, 0,5 \%$ dan $1 \%$ masing-masing yaitu 3,60 (agak suka), 3,45 (agak suka), 2,90 (tidak suka), 3,30 (agak suka), 3,50 (agak suka) dan 2,65 (tidak suka). Tekstur sambal yang dihasilkan mengental, penambahan $\mathrm{CMC}$ dengan konsentrasi 1\% menunjukkan penilain paling rendah yaitu $2,90 \%$ (tidak suka) dan 2,65\% (tidak suka), dimana tekstur yang di hasilkan mengental sehingga kurang disukai oleh panelis.

CMC mampu menjadi penstabil dalam campuran dan memiliki fungsi pengental sehingga akan mempengaruhi nilai viskositas dari sambal. Diperlukan susunan campuran optimal antara rasio penambahan air dan konsentrasi CMC agar didapatkan viskositas yang disukai oleh konsumen. Menurut Mustamanah (2012), pengemulsi, pemantap dan pengental (emulsifier, stabilizer) adalah bahan tambahan makanan yang dapat membantu terbentuknya terbentuknya atau memantapkan sistem dispersi yang homogen pada makanan. Bahan tambahan makanan ini biasanya ditambahkan pada makanan yang mengandung air dan minyak, misalnya saus selada, margarini, saus, sambal, dan es krim. 
Tabel 5. Nilai Rerata Uji Organoleptik Tekstur Sambal Cabe

\begin{tabular}{|c|c|c|c|}
\hline Perlakuan & \multicolumn{3}{|c|}{ Tekstur } \\
\hline \multirow{2}{*}{ Garam } & \multicolumn{3}{|c|}{ CMC } \\
\cline { 2 - 4 } & $\mathbf{0 \%}$ & $\mathbf{0 , 5 \%}$ & $\mathbf{1 \%}$ \\
\hline $\mathbf{2 \%}$ & $3,60^{\mathrm{a}}$ & $3,45^{\mathrm{ab}}$ & $2,90^{\mathrm{bc}}$ \\
\hline $\mathbf{2 , 5 \%}$ & $3,30^{\mathrm{abc}}$ & $3,50^{\mathrm{ab}}$ & $2,65^{\mathrm{c}}$ \\
\hline
\end{tabular}

Ket : Angka yang diikuti oleh kode huruf yang berbeda menunjukkan adanya perbedaan yang nyata pada taraf signifikansi $5 \%$. Ket Skala : 1= sangat tidak suka; 2 = tidak suka; $3=$ agak suka; $4=$ suka; $5=$ sangat suka

\section{KESIMPULAN}

Hasil analisis TPC sambal cabe dengan perlakuan konsentrasi garam $(2 \%$ dan $2,5 \%)$ dan $\mathrm{CMC}(0 \%, 0,5 \%$ dan $1 \%)$ berkisar antara $0 \times 10^{3}$ hingga $1 \times 10^{3}$, menunjukkan perbedaan yang nyata.

Hasil analisis total padatan sambal cabe dengan perlakuan konsetrasi garam $(2 \%$ dan $2,5 \%)$ dan CMC $(0 \%, 0,5 \%$ dan $1 \%)$ berkisar antara 26,90\% hingga 40,12\%, menunjukkan perbedaan yang nyata.

Hasil uji organoleptik terhadap rasa sambal cabai berkisar antara 2,95 (agak suka) hingga 3,55 (agak suka) menunjukkan perbedaan yang nyata, terhadap warna sambal berkisar antara 3,05 (agak suka) hingga 3,45 (agak suka) menunjukkan tidak beda nyata dan hasil uji organoleptik terhadap tekstur sambal cabe berkisar antara 2,65 (tidak suka) hingga 3,60 (agak suka) menunjukkan perbedaan yang nyata.

\section{DAFTAR PUSTAKA}

Anonim. 2007. Macam, Jenis, Manfaat dan Bahaya Garam. http://www.ubb.ac.id/menulengkap .php? judul=Macam,\%20Jenis, $\% 2$ OManfaat\%20dan\%20Bahaya\%20 Garam\&\&nomorurut_artikel=255 - Diakses tanggal 10 Februari 2012.

Anonim, 2009. Budidaya Cabe Rawit http://cazava.blogspot.com/2011/0 7/kandungan-manfaat-cabedalam-kesehatan.html..

Boga, Y. 2004. Saus Sambal Cabai. Gramedia Pustaka Utama: Jakarta.

Rahayu, W.P. 2000. Aktivitas Antimikroba Bumbu Masakan Tradisional Hasil Olahan Industri Terhadap Bakteri Patogen dan Perusak. Buletin Teknologi dan Industri Pangan. Vol.XI, No.2

Suprapti, L. 2000. Membuat Saos Tomat. Trubus Agrisarana, Jakarta

Tamaroh, Siti. 2004. Usaha Peningkatan Stabilitas Nektar Buah Jambu Biji (Psidium guajava L) dengan Penambahan Gum Arab Dan CMC (Carboxy Methyl Cellulose). LOGIKA : Vol.1 No.1, Januari $2004: 56-64$ 